\title{
Expression and Subcellular Targeting of Human Complement Factor C5a in Nicotiana species
}

\author{
Henrik Nausch ${ }^{1}$, Heike Mischofsky ${ }^{1}$, Roswitha Koslowski ${ }^{2}$, Udo Meyer ${ }^{2}$, Inge Broer ${ }^{1 *}$, Jana Huckauf ${ }^{1}$ \\ 1 Department of Agrobiotechnology, Agricultural and Environmental Faculty, University of Rostock, Rostock, Germany, 2 Bioserv GmbH, Rostock, Germany
}

\begin{abstract}
We evaluated transgenic tobacco plants as an alternative to Escherichia coli for the production of recombinant human complement factor $5 \mathrm{a}$ ( $\mathrm{C} 5 \mathrm{a}$ ). $\mathrm{C} 5 \mathrm{a}$ has not been expressed in plants before and is highly unstable in vivo in its native form, so it was necessary to establish the most suitable subcellular targeting strategy. We used the strong and constitutive CaMV $35 \mathrm{~S}$ promoter to drive transgene expression and compared three different subcellular compartments. The yields of $\mathrm{C}^{\mathrm{a} a} \mathrm{a}$ in the $\mathrm{T}_{0}$ transgenic plants were low in terms of the proportion of total soluble protein (TSP) when targeted to the apoplast (0.0002\% TSP) or endoplasmic reticulum $(0.0003 \%$ TSP) but was one order of magnitude higher when targeted to the vacuole $(0.001 \%$ TSP). The yields could be increased by conventional breeding (up to $0.014 \%$ TSP in the $\mathrm{T}_{2}$ generation). C5a accumulated to the same level in seeds and leaves when targeted to the apoplast but was up to 1.7-fold more abundant in the seeds when targeted to the ER or vacuole, although this difference was less striking in the better-performing lines. When yields were calculated as an amount per gram fresh weight of transgenic plant tissue, the vacuole targeting strategy was clearly more efficient in seeds, reaching $35.8 \mu \mathrm{g}$ C5a per gram of fresh seed weight compared to $10.62 \mu \mathrm{g}$ C5a per gram fresh weight of leaves. Transient expression of C5aER and C5aVac in N. benthamiana, using MagniCON vectors, reached up to $0.2 \%$ and $0.7 \%$ of TSP, respectively, but was accompanied by cytotoxic effects and induced leaf senescence. Western blot of the plant extracts revealed a band matching the corresponding glycosylated native protein and the bioassay demonstrated that recombinant C5a was biologically active.
\end{abstract}

Citation: Nausch H, Mischofsky H, Koslowski R, Meyer U, Broer I, et al. (2012) Expression and Subcellular Targeting of Human Complement Factor C5a in Nicotiana species. PLoS ONE 7(12): e53023. doi:10.1371/journal.pone.0053023

Editor: Alfredo Herrera-Estrella, Cinvestav, Mexico

Received August 1, 2012; Accepted November 22, 2012; Published December 28, 2012

Copyright: (c) 2012 Nausch et al. This is an open-access article distributed under the terms of the Creative Commons Attribution License, which permits unrestricted use, distribution, and reproduction in any medium, provided the original author and source are credited.

Funding: The first author appreciated the grant from the doctorate program of the University of Rostock. The funders had no role in study design, data collection and analysis, decision to publish, or preparation of the manuscript. No additional external funding was received for this study.

Competing Interests: For the purpose of transparency, the authors declare the affiliation to the company BIOSERV in detail. The experiments for this publication were done in cooperation with the commercial company BIOSERV GmbH. The company provided the equipment for the Bioassay in order to test the biological activity of plant-made C5a. That is why, the employees of BIOSERV, which were involved in the Bioassay experiments, were listed as co-authors. There are not any competing interests between the University of Rostock and BIOSERV, since this study was done as cooperation project. All authors are informed about and agreed with the submitted manuscript. None of the authors from the University of Rostock have been employed by BIOSERV at any time. Furthermore, there are no patents, products in development or marketed products etc., which compete with the manuscript. Hence, this does not alter the authors' adherence to all the PLOS ONE policies on sharing data and materials.

*E-mail: inge.broer@uni-rostock.de

\section{Introduction}

Autoimmune and inflammatory diseases (AIIDs) are characterized by an overactive immune system. They are becoming more prevalent in society and more of a significant challenge to health authorities around the world. Particularly sepsis following bacterial infection often fail standard medical treatments due to the spread of antibiotic resistance [1]. With mortality rates exceeding $70 \%$, sepsis is one of the top 10 causes of death worldwide [1-4]. Therefore, there is a strong demand for novel therapeutic approaches to regulate the immune system. Complement factor $5 \mathrm{a}$ (C5a) is a promising candidate for immunomodulatory therapies of sepsis [4-7], since it has been characterised as potent mediator of the innate immune system to infection and 'key' mediator of sepsis and septic organ dysfunction [1,4-12]. Though, the development of this strategy is hampered by the lack of an efficient production system for recombinant C5a.

Recombinant pharmaceutical proteins are usually produced by fermentation in Escherichia coli, yeast, insect cells or mammalian cells, each with particular advantages and disadvantages often depending on the importance of post-translational modifications for therapeutic efficacy [13]. C5a produced in E. coli accumulates as inclusion bodies and therefore requires laborious solubilisation and refolding to achieve the native confirmation [14-16]. Attempts to express soluble C5a in E. coli have only been partially successful [17]. The solubilisation of inclusion bodies is undesirable in commercial downstream processing because of the increased process time and costs [18], therefore E. coli is not suitable for the commercial production of $\mathrm{C} 5 \mathrm{a}$.

In contrast to microbes, plants can fold and modify complex human proteins and should therefore be able to produce C5a in a soluble and active form [19]. Plants also have the advantage of economy, scalability and increased safety compared to animal cells, since they do not support the replication of human pathogens [20,21]. Among the many plant species used for the production of recombinant proteins, tobacco (Nicotinana tabacum) is regarded as a major emerging platform for the production of certain pharmaceutical products, especially subunit vaccines and antibodies [2224]. Tobacco is a leafy crop that produces up to 100 tons of leaf biomass per hectare and the total soluble protein (TSP) content is higher than in many other plant species [19]. Tobacco is neither a food nor a feed crop, thus reducing the likelihood of transgenic 
material contaminating the food or feed chain. Tobacco has also proven to be compatible with the demands of good manufacturing practice (GMP), which is critical for the regulatory approval of plant-derived pharmaceuticals [25]. Proof of concept has been demonstrated for various antibodies, subunit vaccines, hormones and enzymes, including other blood factors which have successfully been produced in tobacco with a yield of up to $0.15 \%$ TSP in leaves [19]. Several plant-derived pharmaceutical proteins have successfully completed phase I clinical trials to demonstrate safety, and many plant derived vaccines have also demonstrated efficacy by inducing a significant immune response [23,26].

Our objective was to demonstrate the use of tobacco to produce recombinant human $\mathrm{C} 5 \mathrm{a}$. We compared different targeting strategies for their impact on protein yields, since it has been demonstrated in many previous studies that targeting proteins to different tissues and subcellular compartments is more successful than letting them accumulate in the cytosol or testing a single tissue [27]. We therefore compared proteins targeted to the apoplast, endoplasmic reticulum (ER) and protein storage vacuoles (PSVs) in leaves and seeds. We selected the commercial tobacco cultivar $\mathcal{N}$. tabacum cv. Geudertheimer as the production host because of its superior biomass yield. In addition, as alternative to stable transformation, we investigated the feasibility of the MagnICON-based transient expression system for the expression of $\mathrm{C} 5 \mathrm{a}$ in $\mathcal{N}$. benthamiana.

\section{Materials and Methods}

\section{Construction of plant expression vectors}

We designed a synthetic C5a coding region based on the 74amino-acid sequence of the human complement factor C5a, a cleavage product of the precursor protein C5 (accession no. P01031 |678aa/Fig. S2). This was codon optimized for expression in tobacco (http://www.kazusa.org). The coding region was supplemented with a 28-amino-acid N-terminal ER-targeting peptide from the human IL6 gene (accession no. P05231-1) as shown in figure $\mathrm{Sl}$. We also added three codons (GCT TCG TCG) after the ATG initiation codon to improve the efficiency of translation [28]. These constructs were synthesized by the DNA Cloning Service (Hamburg, Germany).

We used the binary transformation vector pLH9000 (accession no. AF458478 [29]) containing the neomycin phosphotransferase type II gene $(n p t I I)$ for selection [30] and ColE1 and VS1 origins of replication for propagation in E. coli and Agrobacterium tumefaciens, respectively. We inserted a polylinker and expression cassette comprising the CaMV 35S promoter with double enhancer [31], the tobacco mosaic virus (TMV) $\Omega$-fragment [32] and the CaMV terminator [31] at the SfiI site, and then integrated the abovementioned synthetic gene constructs at the BamHI/EcoRI sites in the polylinker. The protein expressed using this basic cassette was targeted to the apoplast. For ER and vacuolar targeting, synthetic oligonucleotide sequences were designed based on the SEKDEL ER-retention signal [33], and the vacuole sorting determinant AFVY from phaseolin [34] as shown in figure S3. The synthesized oligonucleotides (Invitrogen) were fused to the 3 '-end of the coding region at the MunI/BsrgI sites. All vectors were verified by DNA sequencing (GATG Biotech AG, Konstanz/Germany).

We used transient expression vectors based on Tobacco mosaic virus (cr-TMV/TVGV) provided by Prof. Dr. Yuri Gleba and Dr. Anatoli Giritch (Nomad Bioscience; Halle/Saale, Germany). These are derivatives of pICH18711, which has been optimized for high yields [35]. The pICH18711 vector is similar to pICH29912 except the green fluorescent protein (GFP) coding region has been inserted into the BsaI cloning site of pICH29912.
The coding region of $\mathrm{C} 5 \mathrm{aER}$ and $\mathrm{C} 5 \mathrm{aVac}$ was incorporated together with flanking BsaI restriction sites into the vector pLC by DNA Cloning Service Hamburg. The coding regions were inserted into the BsaI site of pICH29912 as described [36]. The vectors were verified by sequencing with primer pairs TMV-fw and TMV-rv (Table 1). The transient expression vectors were introduced into Agrobacterium tumefaciens strain ICF 320, a disarmed, auxotrophic derivative $(\Delta$ cysKa,$\Delta$ cysKb, $\Delta$ thiG) of strain C58 [37].

\section{Stable transformation of tobacco plants}

Wild type tobacco (Nicotiana tabacum cv. Geudertheimer) seeds were surface sterilized in saturated calcium hypochlorite solution and $0.1 \%$ Triton $\mathrm{X}-100$ for $5 \mathrm{~min}$. The seeds were rinsed several times with sterilized distilled water to remove the detergent and allowed to germinate on $4.4 \mathrm{~g} / \mathrm{l}$ Linsmaier and Skoog (LS) medium including vitamins (catalog no. L0230.0050; Duchefa, Belgium) supplemented with $30 \mathrm{~g} / 1$ sucrose and $6.5 \mathrm{~g} / 1$ plant agar (catalog no. P1001.1000; Duchefa, Belgium) and adjusted to $\mathrm{pH}$ 5.7. The plants were maintained at $24 / 22^{\circ} \mathrm{C}$ day/night temperature with a 16-h photoperiod.

Tobacco leaves approximately one month old were used for Agrobacterium-mediated transformation essentially as described [38] but optimized for the transformation of cultivar Geudertheimer by Tina Hausmann (personal communication). Regenerated shoots were selected on LS medium containing $100 \mu \mathrm{g} / \mathrm{ml}$ kanamycin and $500 \mu \mathrm{g} / \mathrm{ml}$ cefotaxim. Regenerated plants were transferred to peat soil in the greenhouse until they were mature. Transgene integration was confirmed by PCR (Table 1).

\section{Transient expression in tobacco leaves}

Transient expression in $\mathcal{N}$. plants (6-9 weeks old) was carried out as described by Giritch et al. [39]. A bacterial smear was inoculated into $5 \mathrm{ml}$ starter culture containing $50 \mu \mathrm{g} / \mathrm{ml}$ rifampicin and $50 \mu \mathrm{g} / \mathrm{ml}$ kanamycin, and was incubated overnight $28^{\circ} \mathrm{C}$, $220 \mathrm{rpm}$. The overnight culture was sedimented $(10 \mathrm{~min}$, $4500 \mathrm{rpm}, 4^{\circ} \mathrm{C}$ ) and the pellet was resuspended in $50 \mathrm{ml}$ infiltration buffer containing $10 \mathrm{mM}$ MES (pH 5.5) and $10 \mathrm{mM}$ $\mathrm{MgCl}_{2}$ (1:100 dilution).

\section{DNA analysis}

The T-DNA cassette was detected by PCR analysis of crude leaf extracts prepared from $100 \mathrm{mg}$ of leaf tissue homogenized under liquid nitrogen and resuspended in $200 \mu \mathrm{l}$ of extraction buffer (50 mM NaOH, 0.25\% SDS). After boiling for $10 \mathrm{~min}$ and pelleting in a bench centrifuge, the supernatant was diluted 1:5 in distilled water. PGR was used to detect both the C5a gene and the nptII marker. After an initial denaturation step $\left(95^{\circ} \mathrm{C}\right.$ for $\left.5 \mathrm{~min}\right)$ we carried out 39 amplification cycles $\left(95^{\circ} \mathrm{C}\right.$ for $1 \mathrm{~min}, 58^{\circ} \mathrm{C}$ for $1 \mathrm{~min}, 72^{\circ} \mathrm{C}$ for $\left.2 \mathrm{~min}\right)$ and a final elongation step $\left(72^{\circ} \mathrm{C}\right.$ for $10 \mathrm{~min})$. The primer pairs are listed in Table 1.

\section{RNA analysis}

Total RNA was isolated from $100 \mathrm{mg}$ tobacco leaf tissue using Trizol reagent according to the manufacturer's instructions (Invitrogen). RNA integrity was assessed by visualizing the $28 \mathrm{~S}$ and $18 \mathrm{~S}$ rRNA bands under UV light in a denaturing $0.8 \%$ MOPS-agarose gel containing ethidium bromide. For reverse transcription (RT)-PCR analysis, total RNA samples were digested with DNase for $3 \mathrm{~h}$ and the removal of DNA confirmed by PCR against the endogenous actin sequence, which generates different products from genomic DNA and cDNA templates [40]. We used the RevertAid ${ }^{\text {TM }} \mathrm{H}$ Minus First Strand cDNA Synthesis Kit 
Table 1. Primers used for PCR and RT-PCR analysis.

\begin{tabular}{|c|c|c|c|c|}
\hline \multicolumn{2}{|c|}{ Forward-Primer } & \multicolumn{2}{|c|}{ Reverse Primer } & \multirow{2}{*}{ Product length } \\
\hline Name & Sequence & Name & Sequence & \\
\hline $\mathrm{NtC5}-\mathrm{fw}$ & 5'-CCTGCTGCATTTCCTGCGAC-3' & $\mathrm{NtC5a-rv}$ & 5'-ACGACACAGCACTCTGTGAAGG-3 & $166 \mathrm{bp}$ \\
\hline NtC5a-fw & 5'-CCTGCTGCATTTCCTGCGAC-3' & NtC5aER-rv & 5'-GCTCATCCTTCTCAGACAGTC-3' & $268 \mathrm{bp}$ \\
\hline $\mathrm{NtC5}-\mathrm{fw}$ & 5'-CCTGCTGCATTTCCTGCGAC-3' & NtC5aVac-rv & 5'-GTACACGAAAGCCAGTCTG-3' & $268 \mathrm{bp}$ \\
\hline $2 n p t-f w$ & 5'-TCCGGCCGCTTGGGTGGAGAG-3' & $2 n p t-r v$ & 5'-CTGGCGCGAGCCCCTGATGCT-3' & $450 \mathrm{bp}$ \\
\hline Actin-fw & 5'-GCAACTGGGATGATATGGAGAA-3' & Actin-rv & 5'-GTGCCTTTGCAATCCACATCTG-3' & $850 \mathrm{bp}$ \\
\hline TMV-fw & 5'-GATCCGGACGTCGAAGGTTTCGAAGG-3' & TMV-rv & 5'-CTTGACTCTAGCTAGAGCGGCCGCTGG-3' & 977 bp/971 bp* \\
\hline
\end{tabular}

*plCH29912-C5aER and plCH29912-C5aVac.

doi:10.1371/journal.pone.0053023.t001

(Fermentas, St. Leon-Rot, Germany) according to the manufacturer's recommendations, with each reaction comprising $1 \mu \mathrm{g}$ of DNase-treated RNA, $10 \mathrm{mM}$ dNTP mix, $0.5 \mu \mathrm{g}$ oligo(dT)-primer, the supplied $1 \times$ reaction buffer and $200 \mathrm{U}$ reverse transcriptase. The reaction was incubated at $42^{\circ} \mathrm{C}$ for $60 \mathrm{~min}$ then stopped by heating to $70^{\circ} \mathrm{C}$ for $10 \mathrm{~min}$. The PGR was carried out using the same parameters described for DNA amplification, but we used multiplex conditions including actin-specific primers so that transgene expression could be compared to the endogenous actin gene. The amplified PCR products were separated by $1.5 \%$ TAEagarose gel electrophoresis in gels containing ethidium bromide for visualization.

\section{Southern blot analysis}

Genomic DNA was extracted from $3 \mathrm{~g}$ of leaf tissue using the cetyltrimethylammonium bromide (CTAB) method [41], and $50 \mu \mathrm{g}$ of genomic DNA was digested overnight, separated by $1 \%$ TBE-agarose gel electrophoresis and transferred to a positively-charged nylon membrane (BioDyne ${ }^{\circledR}$ A $0.45 \mu \mathrm{m}$; Pall Life Science VWR; Darmstadt, Germany) by capillary blotting in $10 \times$ SSC. The DNA was fixed by UV cross-linking. The membranes were prehybridized in SDS phosphate buffer $(7 \%$ SDS, $50 \mathrm{mM}$ phosphate buffer ( $\mathrm{pH} 7.0), 2 \%$ blocking reagent (Roche, Mannheim, Germany), 50\% formamide, $5 \times \mathrm{SSC}, 0.1 \%$ sodium lauroyl sarcosinate) at $42^{\circ} \mathrm{C}$ for $2 \mathrm{~h}$ and probed with a DIG-labeled PCR fragment at $42^{\circ} \mathrm{C}$ overnight. Double-strand DIG-labeled DNA probes were prepared by PCR with constructspecific primers (Table 1) using the corresponding binary vectors as the template and the DIG DNA Labeling Kit (Roche Mannheim, Germany). The probes were denatured by boiling for $10 \mathrm{~min}$ before hybridization. Membranes were washed twice at room temperature with $2 \times \mathrm{SSC}, 0.1 \% \mathrm{SDS}$ for $15 \mathrm{~min}$, and then twice with $0.1 \times \mathrm{SSC}, 0.1 \% \mathrm{SDS}$ at $68^{\circ} \mathrm{C}$ for $20 \mathrm{~min}$. Signal detection with an alkaline phosphatase-conjugated anti-DIG antibody was carried out using the DIG Nucleic acid Detection Kit (Roche, Mannheim, Germany). Blots were exposed on Kodak Biomax light film (VWR, Darmstadt, Germany).

\section{Enzyme-linked immunosorbent assay (ELISA)}

Leaf samples $(150 \mathrm{mg}$ ) were homogenized in liquid nitrogen and resuspended in $250 \mu \mathrm{l}$ cold protein extraction buffer $(250 \mathrm{mM}$ sucrose, $50 \mathrm{mM}$ Tris (pH 7.5), 1 mM EDTA, 2 mM PMSF, $0.1 \%$ Triton X-100). For seed samples, $150 \mathrm{mg}$ homogenized seeds were resuspended in $500 \mu \mathrm{l}$ extraction buffer. Samples were centrifuged for $10 \mathrm{~min}$ in a cooled bench-top centrifuge and the protein concentration in the supernatant was measured according to the Bradford (1976) method using Pierce reagent with bovine serum albumin (BSA) as the standard (Thermo scientific, Bonn, Germany).

Recombinant C5a was quantified using a commercial Human Complement Component C5a DuoSet ELISA (catalog no. DY2037; R\&D Systems, Wiesbaden-Nordenstadt, Germany) according to the manufacturer's instructions. Briefly, 96-well plates were coated with a mouse anti-human C5a-specific antibody at a final concentration of $1 \mu \mathrm{g} / \mathrm{ml}$ at room temperature overnight. Following five washes with PBS containing $0.05 \%$ Tween-20, the plates were incubated with $100 \mu$ diluted leaf extract at room temperature for $2 \mathrm{~h}$. After another wash, the plates were incubated with the corresponding biotinylated detection antibody at room temperature for $1 \mathrm{~h}$, washed again and incubated with streptavidin conjugated to horseradish peroxidase at room temperature for $30 \mathrm{~min}$. Finally, the plate was incubated with tetramethylbenzidine (TMB) at room temperature for $15 \mathrm{~min}$ in the dark. The reaction was stopped with $250 \mathrm{mM}$ sulfuric acid. Extinction was measured at $450 \mathrm{~nm}$ in a Synergy HT multidetection reader (BioTek, Bad Friedrichshall, Germany).

\section{Western blot analysis}

Total soluble protein was extracted from leaf and seed samples as described above and $100 \mu \mathrm{g}$ of protein was resuspended in $1 \times$ sample buffer containing $10 \%$ glycerol, $150 \mathrm{mM}$ Tris (pH 6.8), $3 \%$ SDS, $1 \% \beta$-mercaptoethanol and $2.5 \%$ bromophenol blue. The samples were heated to $95^{\circ} \mathrm{C}$ for $5 \mathrm{~min}$ and separated under denaturing conditions by $15 \%$ SDS-PAGE and then electrophoretically transferred to a $0.45-\mu \mathrm{m}$ PVDF membrane (VWR; Darmstadt, Germany). The proteins were transferred at a constant $2 \mathrm{~mA} / \mathrm{cm}^{2}$ at room temperature for $2 \mathrm{~h}$ in a Bio-Rad Trans-Blot semi-dry transfer cell using $50 \mathrm{mM}$ Tris, $40 \mathrm{mM}$ glycine, $0.01 \%$ SDS and $20 \%$ methanol as the transfer buffer ( $\mathrm{pH} 8.5)$. The membrane was blocked using PBS containing 0.05\% Tween-20 and $5 \%$ nonfat milk powder at room temperature overnight and was then probed at room temperature for $2 \mathrm{~h}$ with a mouse monoclonal anti-human-C5a antibody (catalog no. MA1-25341, ABR BioReagents, USA) or rabbit polyclonal anti-human C5a antibody (catalog no. 5995-100; BioVision, Milpitas, USA), each at 1:1000 dilution at room temperature for $2 \mathrm{~h}$. After three washes, the membrane was probed at room temperature for $2 \mathrm{~h}$ with a HRP-conjugated secondary antibody, either goat antimouse (catalog no. 715-035-151; Dianvova, Hamburg, Germany) or donkey anti-rabbit (catalog no. NA934V; GE Healthcare, Munich, Germany), each at 1:10000 dilution. The signal was detected by ECL chemiluminescence and the membrane was exposed to Kodak Biomax light X-ray film (VWR; Darmstadt, Germany) for $1 \mathrm{~min}$ before it was developed and fixed. Carrier- 
A

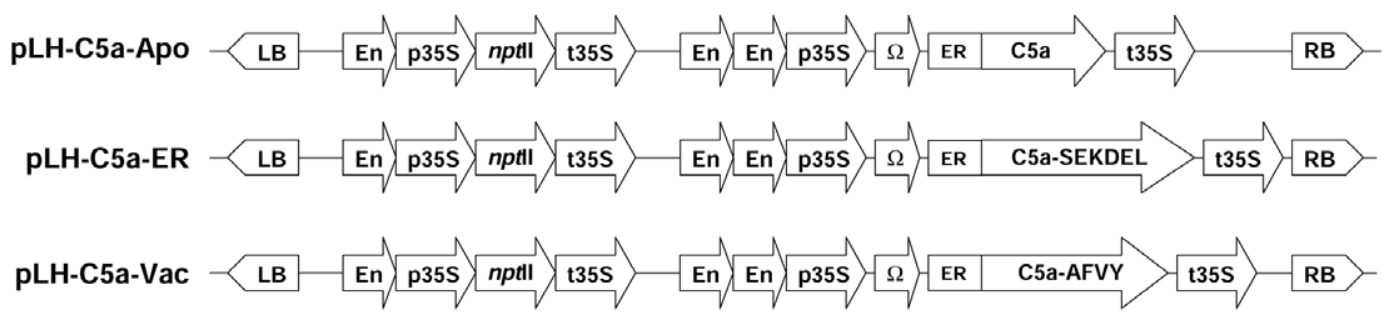

B

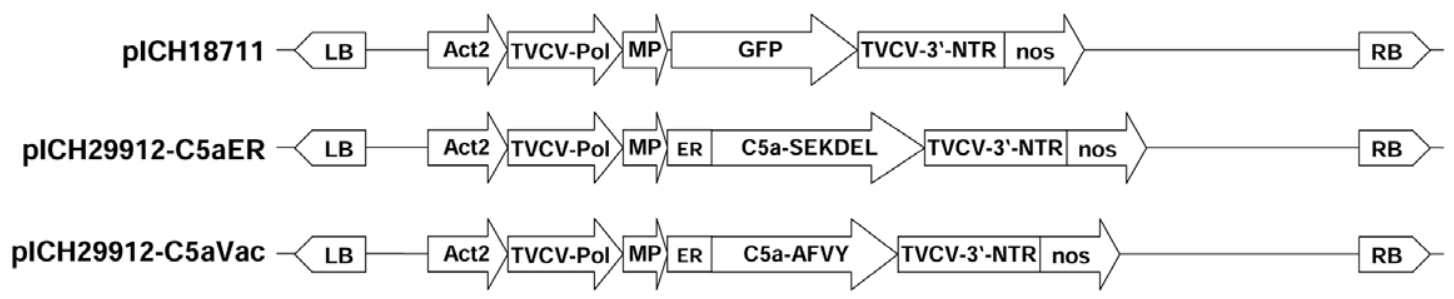

Figure 1. Schematic representations of the T-DNA constructs used to express human C5a in tobacco; (A) vectors used for stable transformation targeting the recombinant protein to different subcellular compartments. LB: left border; RB: right border; En: $-340 \mathrm{bp}$ to -91 bp CaMV $35 \mathrm{~S}$ enhancer; $\mathrm{p} 35 \mathrm{~S}$ : -90 to -1 bp CaMV $35 \mathrm{~S}$ core promoter; $\mathrm{t} 35 \mathrm{~S}$ : CaMV $35 \mathrm{~S}$ terminator; $\Omega$ : 5 ' Tobacco mosaic virus (TMV) untranslated region; nptll: neomycin phosphotransferase gene; ER: codon optimized signal peptide from the human IL6 gene; C5a: synthetic human C5a gene, codon optimized for tobacco; SEKDEL: ER retention motif; AFVY: vacuole-targeting peptide from common bean phaseolin protein; (B) Binary 'MagnICON' vectors used for transient expression. TVCV-Pol: RNA-dependent RNA polymerase from Turnip vein clearing virus (TVCV); MP: TMV movement protein; TVCV-3'-NTR: TVCV 3' untranslated region; nos: A. tumefaciens nopaline synthetase gene terminator. doi:10.1371/journal.pone.0053023.g001

free recombinant human C5a produced in E. coli (catalog no. 2037-C5-025/CF, B\&D Systems, Heidelberg, Germany) was used as a standard.

\section{Determination of C5a biological activity}

C5a activity was detected using a rat basophilic leukemia (RBL) cell-line transfected with human C5aR was used, which was developed by Ali et al. [42]. The cell line was provided by MBM ScienceBridge GmbH (Göttingen, Germany). The bioassay for lysosomal enzyme secretion was conducted as described by Goldstein and Weissmann [43]. The amount of antigenic C5a, applied to the bioassay, was calculated on the basis of the C5aspecific ELISA, which detects the number of antigenic C5a per ml. The concentration was defined as ng C5a equivalents/ml. After incubation with recombinant $\mathrm{C} 5 \mathrm{a}$, the cells are induced to secrete $\mathrm{N}$-acetyl- $\beta$-D-glucosaminidase which releases 4-nitrophenolate from the substrate 4-nitrophenyl-N- $\beta$-D-glucosamide. The photometric detection of 4-nitrophenolate indicates the concentration of active recombinant protein, which can then be defined as an $\mathrm{EC}_{50}$ value. Carrier-free recombinant human C5a produced in E. coli (catalog no. 2037-C5-025/CF, B\&D Systems, Heidelberg, Germany) was used as a standard.

\section{Statistical methods}

Statistical comparisons were carried out using the $F$-test (ANOVA including the Bonferroni post-hoc test) with $p \leq 0.05$ (two-sided) considered significant. The variability of different events and siblings was characterized by the relative coefficient of variation $(\mathrm{CV}, \%) V_{r}[\%]=\frac{1}{\sqrt{n}}-\frac{s}{y}-100$. The experimental design was calculated with SPSS.

\section{Results}

Stable transformation of N. tabacum cv. Geudertheimer The C5a expression vectors for stable expression in tobacco (Fig. 1a) were constructed by incorporating the codon-optimized mature C5a sequence derived from the human C5 pro-protein gene and fusing this to the codon-optimized N-terminal ERtargeting peptide sequence from the human IL6 gene (Fig. S1, S2, S3). Three different variants were created to target the recombinant protein to the apoplast, ER and vacuole. The integrity of all the transformation vectors was verified by DNA sequencing (data not shown).

Putative $\mathrm{T}_{0}$ transgenic plants (grown under kanamycin selection) and non-transgenic controls were tested for the presence on the transgene by PCR on total genomic DNA from the crude leaf extracts, using specific primers (table 1). Transcription was verified by multiplex RT-PCR using the endogenous actin housekeeping gene as an internal control. Products of the expected size were detected in transgenic leaf tissue. The presence of the expected actin cDNA amplification product and the absence of the corresponding genomic product $(1.1 \mathrm{~kb})$ confirmed the absence of genomic DNA contamination (data not shown).

\section{Accumulation of $\mathrm{C} 5 \mathrm{a}$ in the leaves and seeds of $\mathrm{T}_{0}$ transgenic plants}

Crude extracts from the uppermost fully-expanded leaves of 6week-old tobacco plants in the greenhouse were used to determine C5a expression levels by ELISA. The highest yields were achieved by targeting to the vacuole (Fig. 2a). The average yield was $10.6 \mathrm{pg}$ C5a per $\mu \mathrm{g}$ total soluble protein (TSP) and the best-performing event (C5aVac 19) produced $17.4 \mathrm{pg} / \mu \mathrm{g}$ TSP, equivalent to $1.49 \mu \mathrm{g}$ C5a per gram fresh leaf weight (Table 2). The average 
A

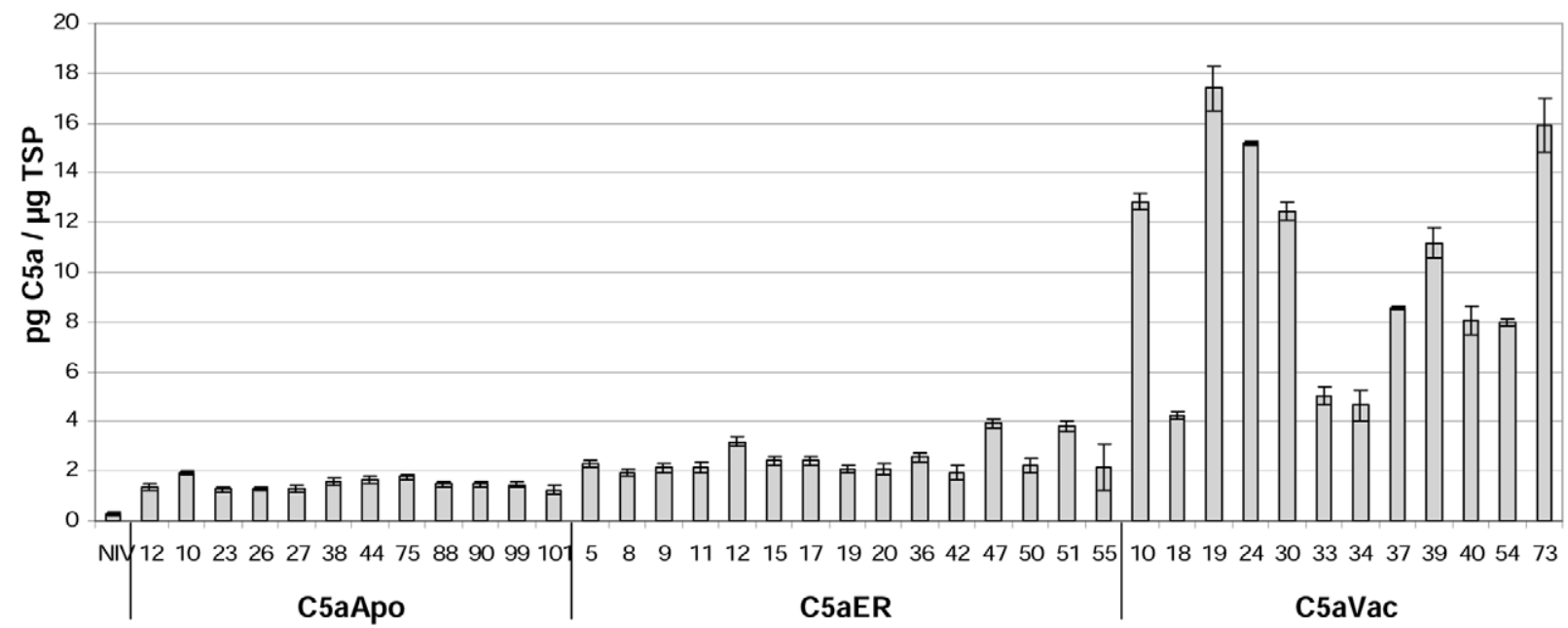

B

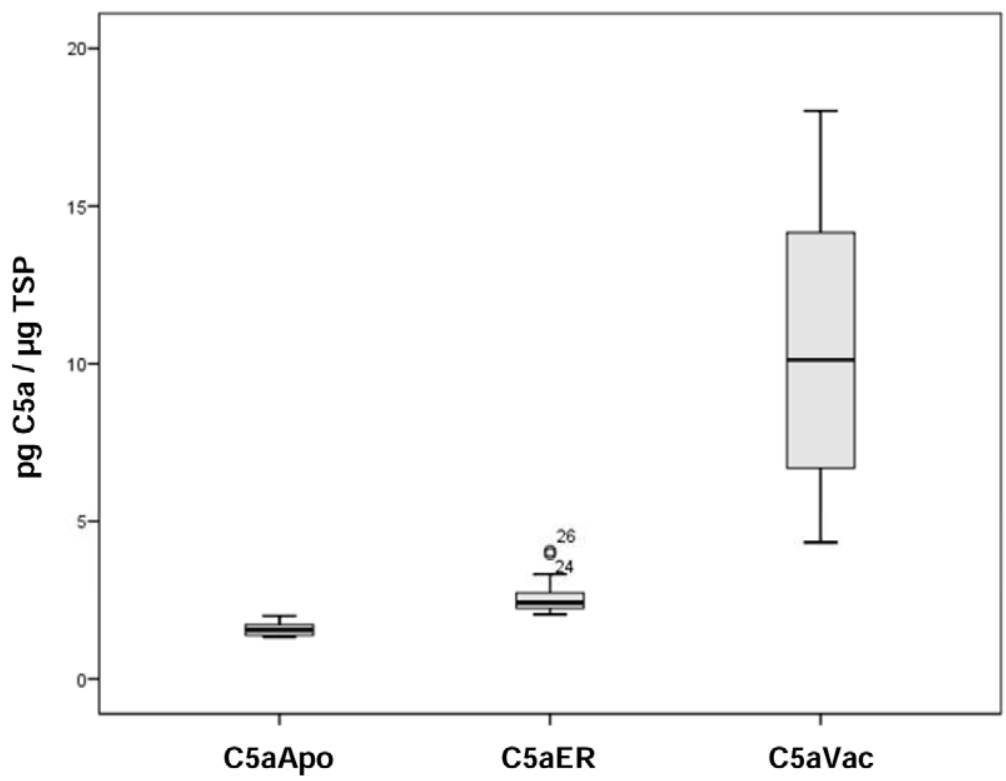

Figure 2. Protein expression levels in leaf extracts from $T_{0}$ transgenic plants determined using at least two ELISAs. (A) Expression level measured in the individual transformants; Lane numbers indicate different independent tobacco events (NIV=wild-type control). (B) Box plot representation of $\mathrm{C} 5 \mathrm{a}$ accumulation in the leaves of $\mathrm{T}_{0}$ transformants following ANOVA (including the Bonferroni post-hoc test). doi:10.1371/journal.pone.0053023.g002

yield of C5a was approximately an order of magnitude lower in the apoplast and ER variants, respectively 1.6 and $2.9 \mathrm{pg} / \mu \mathrm{g}$ TSP. We determined the coefficient of variation $(\mathrm{CV})$ to measure the degree of variability between individual transgenic events (Fig. 2b). This was highest for the $\mathrm{C} 5 \mathrm{aVac}$ construct $(\mathrm{CV}=12.66 \%)$ whereas both C5aApo $(\mathrm{CV}=3.86 \%)$ and C5aER $(\mathrm{CV}=6.38 \%)$ showed relatively low variability.

In order to investigate the accumulation of C5a in seeds and subsequent generations of plants, the ten best-performing $\mathrm{T}_{0}$ plants representing each construct were self-pollinated allowing the collection of $T_{1}$ seeds. Pools of mature seeds weighing $150 \mathrm{mg}$ were harvested from each $\mathrm{T}_{0}$ event, and extracts of total soluble protein were analyzed by ELISA.
Using TSP as the reference parameter (Fig. 3), the average yield of C5aApo was $1.8 \mathrm{pg} / \mu \mathrm{g}$ TSP, which is similar to the level detected in $\mathrm{T}_{0}$ leaves. The yield of C5aER was approximately 1.7fold higher in seeds (4.9 pg/ $\mu \mathrm{g}$ TSP compared to $2.9 \mathrm{pg} / \mu \mathrm{g}$ TSP in leaves; Fig. 4a) and that of $\mathrm{C} 5 \mathrm{aVac}$ was approximately 1.5 -fold higher in seeds $(15.5 \mathrm{pg} / \mu \mathrm{g}$ TSP compared to $10.6 \mathrm{pg} / \mu \mathrm{g}$ TSP in leaves; Fig. 3). The difference between leaves and seeds was less striking in the higher-performing plants, e.g. the yield of C5a in the $\mathrm{T}_{1}$ seeds of the best-performing line C5aVac 19 (18.5 pg/ $\mu \mathrm{g}$ TSP) was only slightly higher than the yield in leaves $(17.4 \mathrm{pg} / \mu \mathrm{g}$ TSP) as shown in table 2.

Using the fresh tissue weight as the reference parameter, C5a yields were approximately four times higher in seeds than leaves, 
Table 2. Expression levels in leaves and seeds of the best-performing line $\mathrm{C} 5 \mathrm{aVac} 19$ and transiently expressed $\mathrm{C} 5 \mathrm{aVac}$, using either TSP or fresh weight as the reference parameter.

\begin{tabular}{|c|c|c|c|c|c|c|c|}
\hline \multirow{2}{*}{$\frac{\text { Construct }}{\text { Generation }}$} & \multicolumn{6}{|c|}{ Stably transformed line C5aVac 19} & \multirow[t]{2}{*}{$\begin{array}{l}\text { Transient expression o } \\
\text { C5aVac }\end{array}$} \\
\hline & \multicolumn{2}{|l|}{$T_{0}$} & \multicolumn{2}{|c|}{$\mathbf{T}_{1}$} & \multicolumn{2}{|l|}{$T_{2}$} & \\
\hline \multirow{2}{*}{ Individual } & \multicolumn{2}{|l|}{19} & \multicolumn{2}{|l|}{ 19-13 } & \multicolumn{2}{|c|}{ 19-13-1 } & \multirow[b]{2}{*}{ leaf } \\
\hline & leaf & seed & leaf & seed & leaf & seed & \\
\hline C5a/TSP & 17.4 & 18.5 & 132.8 & 143.2 & 140.3 & 121.7 & 6985.8 \\
\hline \multicolumn{8}{|l|}{ [pg/ug] } \\
\hline C5a/fresh weight & 1.49 & 4.63 & 10.62 & 35.80 & 11.22 & 30.43 & 558.86 \\
\hline$[\mu \mathrm{g} / \mathbf{g}]$ & & & & & & & \\
\hline
\end{tabular}

doi:10.1371/journal.pone.0053023.t002

regardless of the targeting strategy. Using C5aVac 19 as example, the average yield in leaves was $1.49 \mu \mathrm{g} / \mathrm{g}$ fresh weight, compared to $4.63 \mu \mathrm{g} / \mathrm{g}$ in seeds (Table 2). The $\mathrm{CV}$ values for the variability of expression among different lines were similar to those observed in leaves.

Dry $\mathrm{T}_{1}$ seeds were stored at room temperature for three months and the C5a levels were determined again by ELISA, revealing no significant change in abundance compared to freshly-harvested seeds (data not shown).

\section{Accumulation of $\mathrm{C} 5 \mathrm{a}$ in the leaves and seeds of subsequent generations of plants}

Descendants of the three best-performing $\mathrm{T}_{0}$ transformants (C5aVac 19, 24, 73; see Fig. 3) were self-pollinated to obtain transgenic plants up to the $\mathrm{T}_{2}$ generation, which were selected on kanamycin to ensure the locus remained active. Most of the $T_{1}$ descendants of $\mathrm{C} 5 \mathrm{aVac} 19$ and C5aVac 73 accumulated more C5a than their parents, but there was no generational increase in line C5aVac 24 (Fig. 4a). The expression levels among $\mathrm{T}_{1}$ siblings were relatively heterogeneous, with $\mathrm{CVs}$ of $15.08 \%, 13.64 \%$ and $12.66 \%$ for lines C5aVac 19, 24 and 73, respectively. Some $\mathrm{T}_{1}$ plants accumulated less recombinant protein than their parent (e.g. C5aVac 19-15, which produced $10.6 \mathrm{pg} / \mu \mathrm{g}$ TSP) whereas others produced substantially more (e.g. the best-performing plant
C5aVac 19-13, which produced $132.8 \mathrm{pg} / \mu \mathrm{g}$ TSP, corresponding to $10.62 \mu \mathrm{g} / \mathrm{g}$ fresh leaf weight (Table 2)).

C5aVac 19-13 was self-pollinated and C5a levels were measured in the $\mathrm{T}_{2}$ seeds. The average expression level was $143.2 \mathrm{pg} / \mu \mathrm{g}$ TSP or $35.8 \mu \mathrm{g} / \mathrm{g}$ fresh weight (Table 2) which represents a near eight-fold increase in seeds over one generation. Only two individual $\mathrm{T}_{2}$ plants (C5aVac 19-13-1 and 19-13-15) performed better that their $\mathrm{T}_{1}$ parents (Fig. 4b). Leaves from the best-performing plant (C5aVac 19-13-1) produced $140.3 \mathrm{pg} / \mu \mathrm{g}$ TSP or $11.22 \mu \mathrm{g} / \mathrm{g}$ fresh leaf weight (Table 2). The expressions level among the $\mathrm{T}_{2}$ siblings were less heterogeneous ( $\mathrm{CV}$ of 7.17) compared to the $\mathrm{T}_{1}$ individuals ( $\mathrm{CV}$ of 15.08). The yield of $\mathrm{C} 5 \mathrm{a}$ in the leaves of line $\mathrm{C} 5 \mathrm{aVac} 19$ increased by an order of magnitude between the $T_{0}$ and $T_{1}$ generations but there was only a marginal increase in the $\mathrm{T}_{2}$ generation $(18.3 \rightarrow 132.8 \rightarrow 140.3 \mathrm{pg} / \mu \mathrm{g}$ TSP) was not significant. The accumulation of C5a in the seeds of plant C5aVac $19-13-1 \quad(121.7 \mathrm{pg} / \mu \mathrm{g}$ TSP or $30.4 \mu \mathrm{g} / \mathrm{g}$ fresh seed weight) was slightly lower compared its $\mathrm{T}_{1}$ parent $(143.2 \mathrm{pg} / \mu \mathrm{g}$ TSP). Most $\mathrm{T}_{2}$ descendants of C5aVac 19-13 accumulated less C5a than the $\mathrm{T}_{1}$ parent, although the variability in expression levels was lower $\left(\mathrm{CV}=7.17 \%\right.$ for $\mathrm{T}_{2}$ compared to $15.08 \%$ for $\left.\mathrm{T}_{1}\right)$.

Transgene insertions in the lines C5aVac 19, 24 and 73

We analyzed the transgene locus structure in $\mathrm{T}_{0}$ plants from lines $\mathrm{C} 5 \mathrm{aVac}$ 19, 24 and 73, and in $\mathrm{T}_{1}$ progeny with the highest

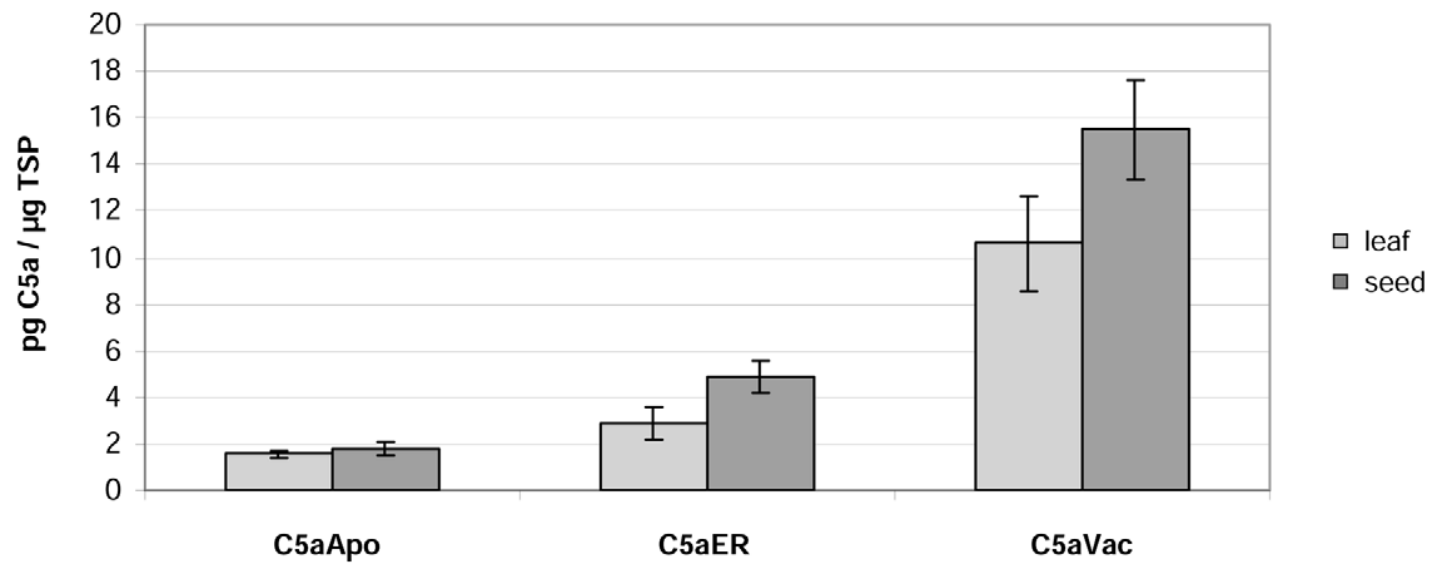

Figure 3. Average protein levels in the leaves and seeds of ten transgenic $T_{0}$ tobacco plants expressing different C5a variants, using TSP as the reference parameter, based on at least two independent ELISAs.

doi:10.1371/journal.pone.0053023.g003 
A

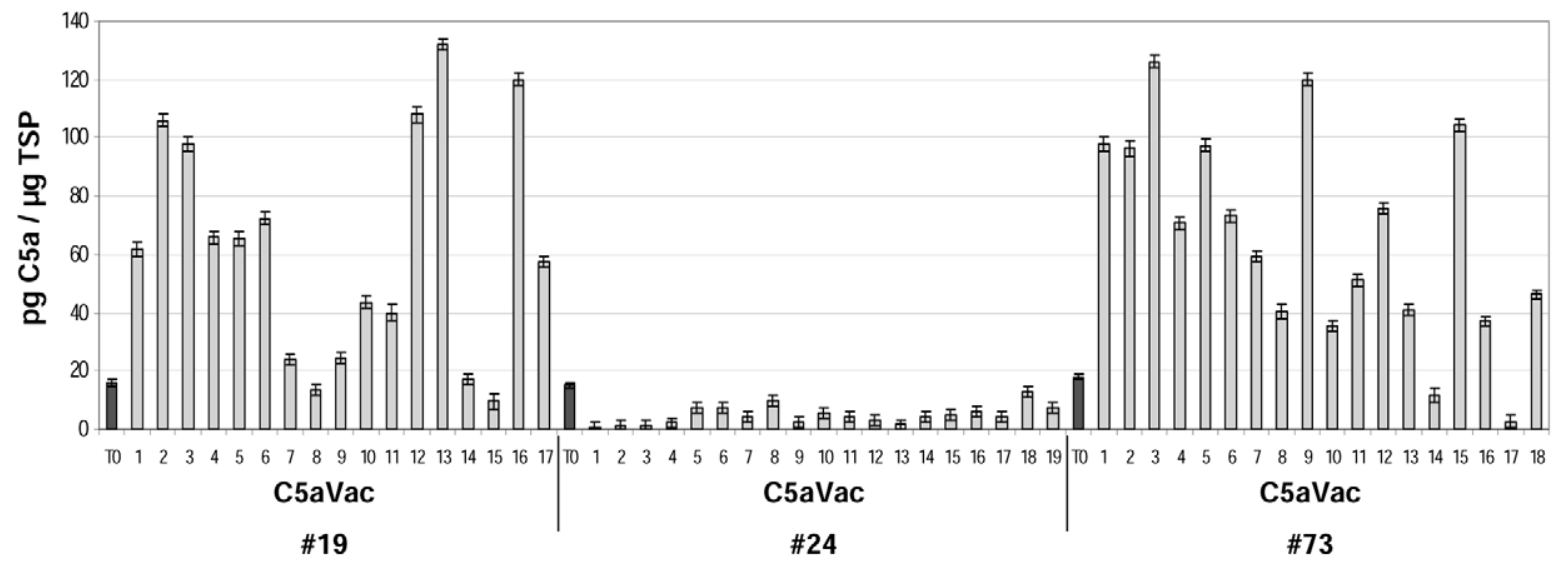

B
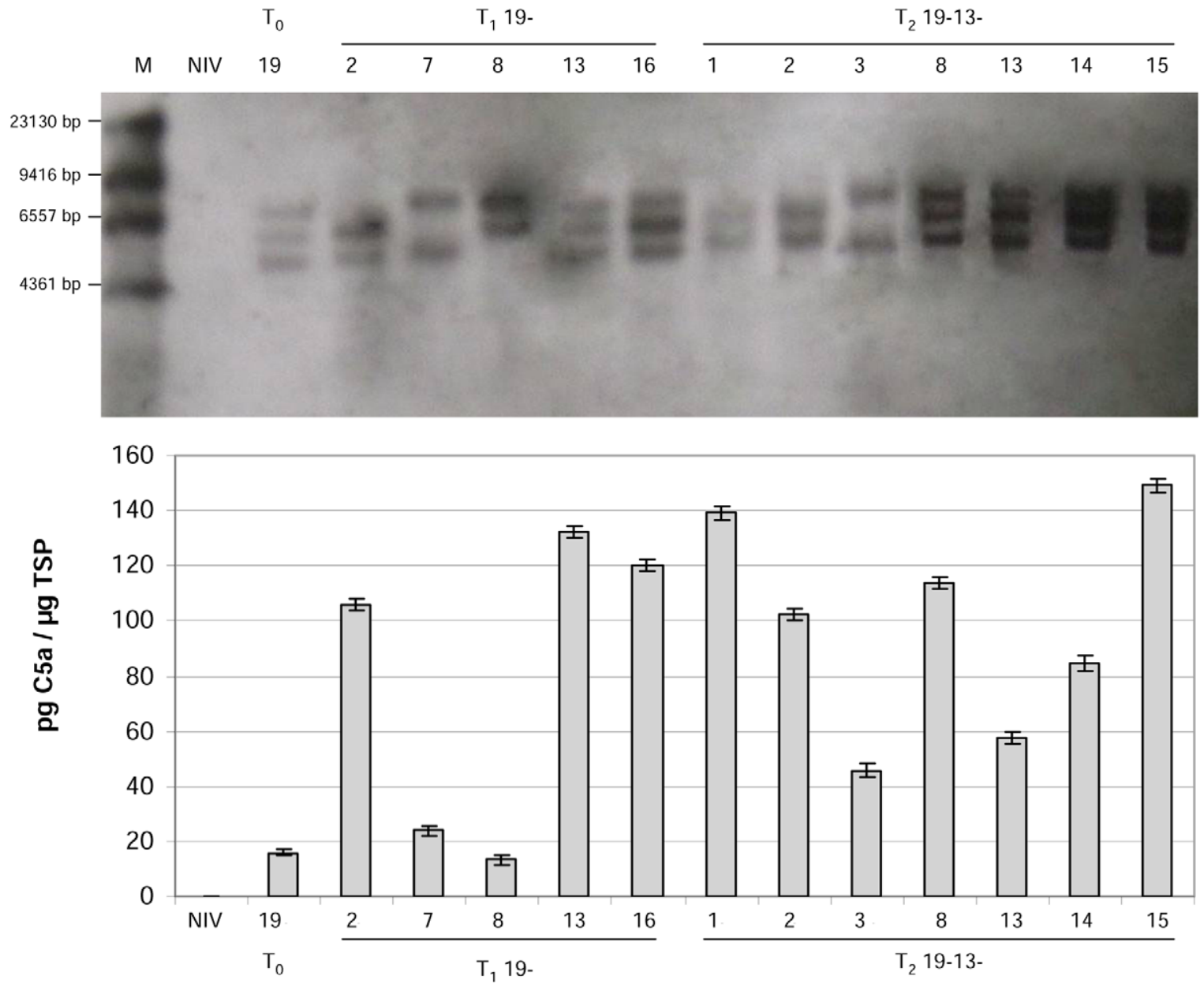

Figure 4. Protein expression levels in the $T_{1}$ generation of three independent transgenic tobacco lines accumulating $C_{5 a}$ in the vacuole, as determined by at least two independent ELISAs. (A) Expression level measured in the individual descendants; Lane numbers represent the different $T_{1}$ individuals and $T_{0}$ represents the parent. (B) Southern blots of the C5aVac $19 T_{0}$ parent and selected $T_{1}$ and $T_{2}$ progeny (identified by lane numbers) and corresponding C5a expression levels determined by ELISA. The genomic DNA was digested with HindIII, which cuts once in the expression vector, and the presence of segregating bands indicates of three unlinked loci in the $T_{0}$ parent. M=DIG-labeled DNA Molecular Weight Marker II (Roche), NIV DNA from wild-type negative control plant.

doi:10.1371/journal.pone.0053023.g004 
A

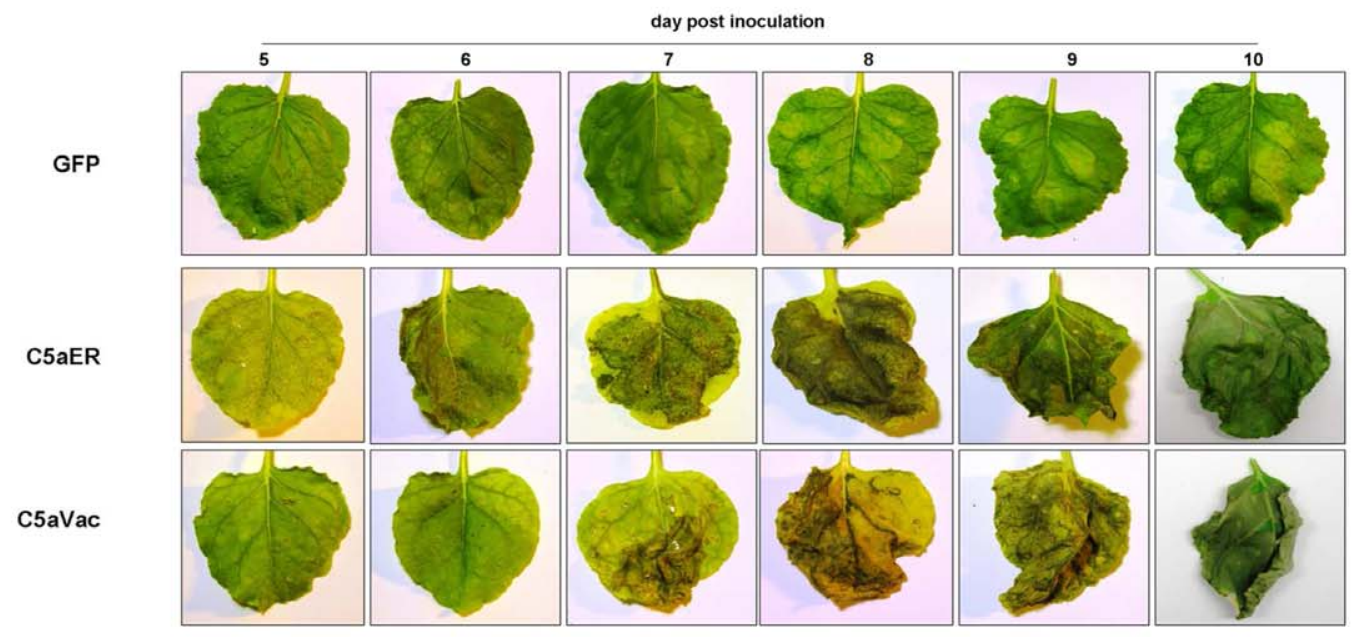

B

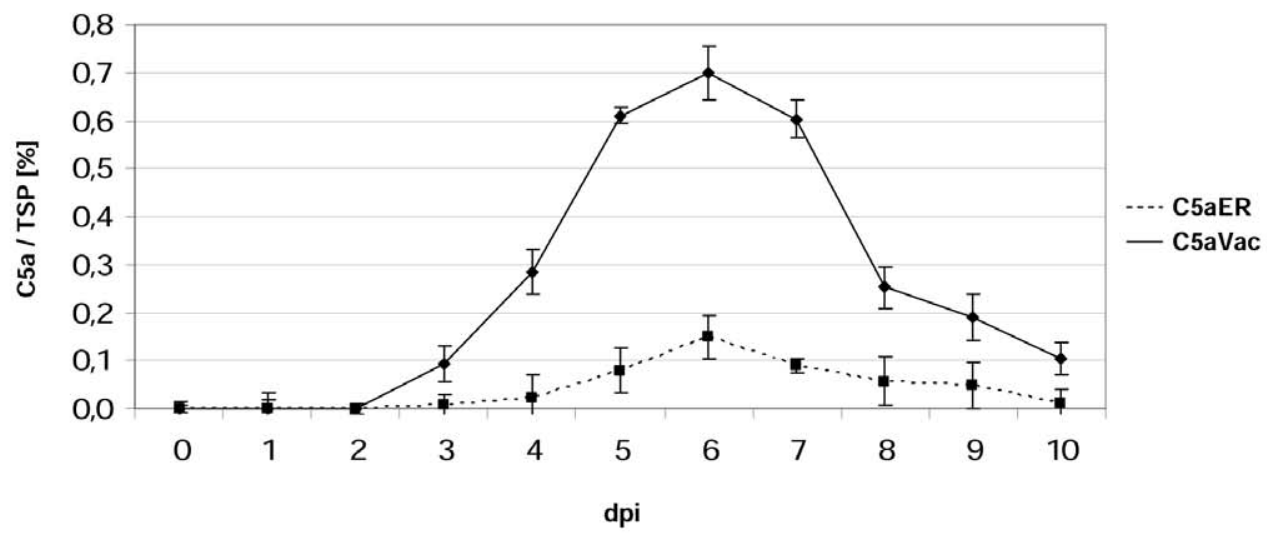

C

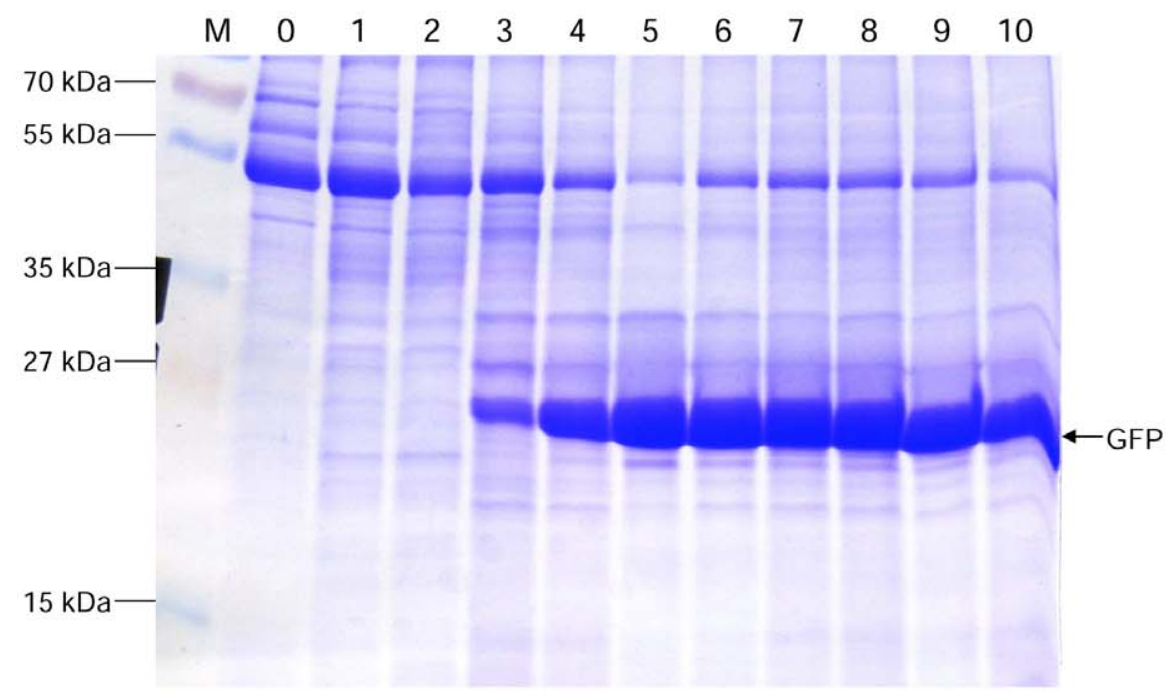


Figure 5. Leaves of $N$. benthamiana Agroinfiltrated with either GFP-, C5aER- or C5aVac-expressing vectors pICH18711, pICH29912C5aER and pICH29912-C5aVac, respectively. One representative of at least three independent experiments is shown. (A) Pictures of leaves made under UV-light prior to sampling. dpi: days post inoculation (B) Yield of recombinant C5a as percentage of TSP in Agroinfiltrated leaves of $N$. benthamiana, sampled from 0-10 dpi. (C) Coomassie-stained SDS-PAGE of leaf extracts N. benthamiana leaves, Agroinfiltrated with GFP-expressing control vector plCH18711, sampled from 0-10 dpi. doi:10.1371/journal.pone.0053023.g005

and lowest expression levels between the corresponding siblings (Fig. 4a), namely 19-2, -7, -8, -13, -16 and 24-4, -6, -8, -13, -16 and $73-3,-9,-10,-14,-15$. We further analysed the $\mathrm{T}_{2}$ individuals $19-$ 13-1, -2, -3, -8, -13, -14, -18 (Fig. 4b). We detected three transgene loci in the $\mathrm{T}_{0}$ plant $\mathrm{C} 5 \mathrm{aVac} 19$, and the two best-performing $\mathrm{T}_{1}$ plants from this line (C5aVac 19-13 and 19-16) retained all three loci whereas the other three lines (C5aVac 19-2, 19-7 and 19-8) retained only two loci (Fig. $4 \mathrm{~b})$. In the $\mathrm{T}_{2}$-generation the highest expression was observed in plants with all three but also with only two loci. As expected for lines with high copy number, the segregation analysis of C5aVac 19; 19-2; 19-7; 19-8; 19-13; 19-16; $19-13-1 ; 19-13-15$ revealed always nearly $100 \%$ transgenic offspring. Hence no correlation between the number of transgene loci and the performance of individual plants was detectable. There were also three transgene loci in the $\mathrm{T}_{0}$ plant C5aVac 73 and these were retained in all five $\mathrm{T}_{1}$ plants we tested (data not shown). Given the highly variable expression levels among these $\mathrm{T}_{1}$ plants, the locus structure did not appear to affect the performance of individual plants. There was a single locus in $\mathrm{T}_{0}$ plant $\mathrm{C} 5 \mathrm{aVac} 24$ and in all five $\mathrm{T}_{1}$ individuals we tested (data not shown).

\section{Transient expression of $\mathrm{C} 5 \mathrm{aER}$ and $\mathrm{C} 5 \mathrm{aVac}$ in $\mathrm{N}$. benthamiana, using the MagnICON system}

For transient expression, the coding regions of C5aER and C5aVac were introduced into the MagnICON vector pICH29912 (Fig. 1b), which was kindly provided by Prof. Dr. Yuri Gleba and Dr. Anatoli Giritch (Nomad Bioscience; Halle/Saale, Germany). We selected these two C5a variants, since in stable transformed plants, the C5aApo and C5aER led to similarly low levels of recombinant protein while $\mathrm{C} 5 \mathrm{aVac}$ revealed significantly higher yield. The tobacco cultivar Geudertheimer, which was used for stable transformation, has been recorded to be not amenable for the MagnICON system [44]. Therefore, we expressed both genes transiently in $\mathcal{N}$. benthamiana, which is commonly used for transient expression assays and known to promote high level expression of viral replicons $[45,46]$. However, overexpression of both C5a variants was accompanied by cytotoxic effects and induced leave senescence whereas no severe phenotype was observed in plants infected with the GFP control vector pICH18711 (Fig. 5a). Moreover, we observed a rapid decline in the yield of the target protein in the dying leaves (Fig. 5b). Nevertheless, the highest accumulation level measured at $6 \mathrm{dpi}$ at the beginning leaf senescence reached up to $0.7 \%$ of TSP for $\mathrm{C} 5 \mathrm{aVac}$ and $0.2 \%$ of TSP for C5aER (Table 2). The difference in the accumulation level between transiently expressed C5aER and C5aVac was similar to the one observed in stable transformed tobacco.

\section{Molecular and functional characterization of recombinant plant-derived $\mathrm{C} 5 \mathrm{a}$}

Western blot analysis of TSP extracts from leaf and seeds samples of transgenic C5aVac plants (Fig. 6a) and transfected $\mathcal{N}$. benthamiana plants (Fig. 6b) showed a distinct band that migrates at $12 \mathrm{kDa}$, which is larger than the recombinant product from $E$. coli $(9 \mathrm{kDa})$ suggesting that the plant-derived recombinant protein might be glycosylated. Crude leaf extracts from the $\mathrm{T}_{2}$ individual C5aVac 19-13-1 and the near isogenic variant as control were used for C5a bioassays based on a RBL-cell line, transfected with an C5a-receptor. The cell line releases an enzyme upon binding of biological active C5a which can be measured by substrate conversion at $405 \mathrm{~nm}$. The concentration of C5a which induced the half-maximal enzyme release was determined as $\mathrm{EC}_{50}$ value. Interestingly, extracts of the near isogenic variant (niv) that served as control converted the substrate as proven by the incubation of mere leaf samples with the substrate (data not shown). Nevertheless, spiked with the C5a standard the NIV induced an additional enzyme release in a dose-dependent manner similar to the commercial C5a standard (Fig. 6c). Hence the basic level of conversion observed in the NIV without additional enzyme was subtracted from the values measured for the transgenic variants. The $\mathrm{EC}_{50}$ value of both samples was calculated at approximately $200 \mathrm{ng} / \mathrm{ml}$. The different concentrations of C5a in the assays were adjusted based on the values measured by C5a-ELISA, in the transgenic leaf and seed extracts. Leaf extracts of C5aVac 19-13-1 induced enzyme release in a manner comparable to the C5a standard but the $\mathrm{EC}_{50}$ value of $279.48 \mathrm{ng} / \mathrm{ml}$ was higher (Fig. 6c). Samples of transgenic plants and seeds and from leaves derived from the transient expression in $\mathcal{N}$. benthamiana, resulted in an equal $\mathrm{EC}_{50}$-value (data not shown). Incubating the transgenic leaf samples with the anti-C5a-antibody, used for the Western Blots, prior to the bioassay, reduced the response to the level of the NIV extract (Fig. 6c).

\section{Discussion}

We have demonstrated for the first time that the human complement factor C5a can be produced in a soluble and active form in stable transformed tobacco, although the yields were low compared to other recombinant proteins expressed using the CaMV 35S promoter $[19,47]$. This may reflect the fact that C5a is an unstable protein that is rapidly degraded in the plasma following its release from the precursor C5 [48,49]. The degradation of recombinant proteins in plants is a relatively common occurrence that limits accumulation in planta, and it is possible that unstable human proteins are also susceptible to endogenous plant proteases [50,51].

Targeting recombinant proteins to different tissues and subcellular storage compartments can significantly influence the protein stability and yield $[27,52]$. In the case of C5a, the vacuole appears to be the most suitable storage compartment, since the highest yields were achieved in leaves and seeds when appending the recombinant protein with the PSV-specific targeting peptide AFVY (Fig. 2a, b). This result was unexpected in leaves because PSVs are underrepresented in vegetative tissues, whereas lytic vacuoles are prevalent that do not support protein accumulation [53]. However, it has been demonstrated that the expression of seed storage proteins in leaves can induce the formation of storage organelles in vegetative tissue [54].

Many heterologous proteins accumulate to higher levels when targeted for retention in the ER because this compartment contains abundant molecular chaperones to fold proteins correctly and maintain their solubility but there are few proteases [50]. This contrasts with the apoplast, where abundant proteases often cause significant degradation $[50,55]$. Interestingly, we did not find a significant difference between these compartments and C5a 
A
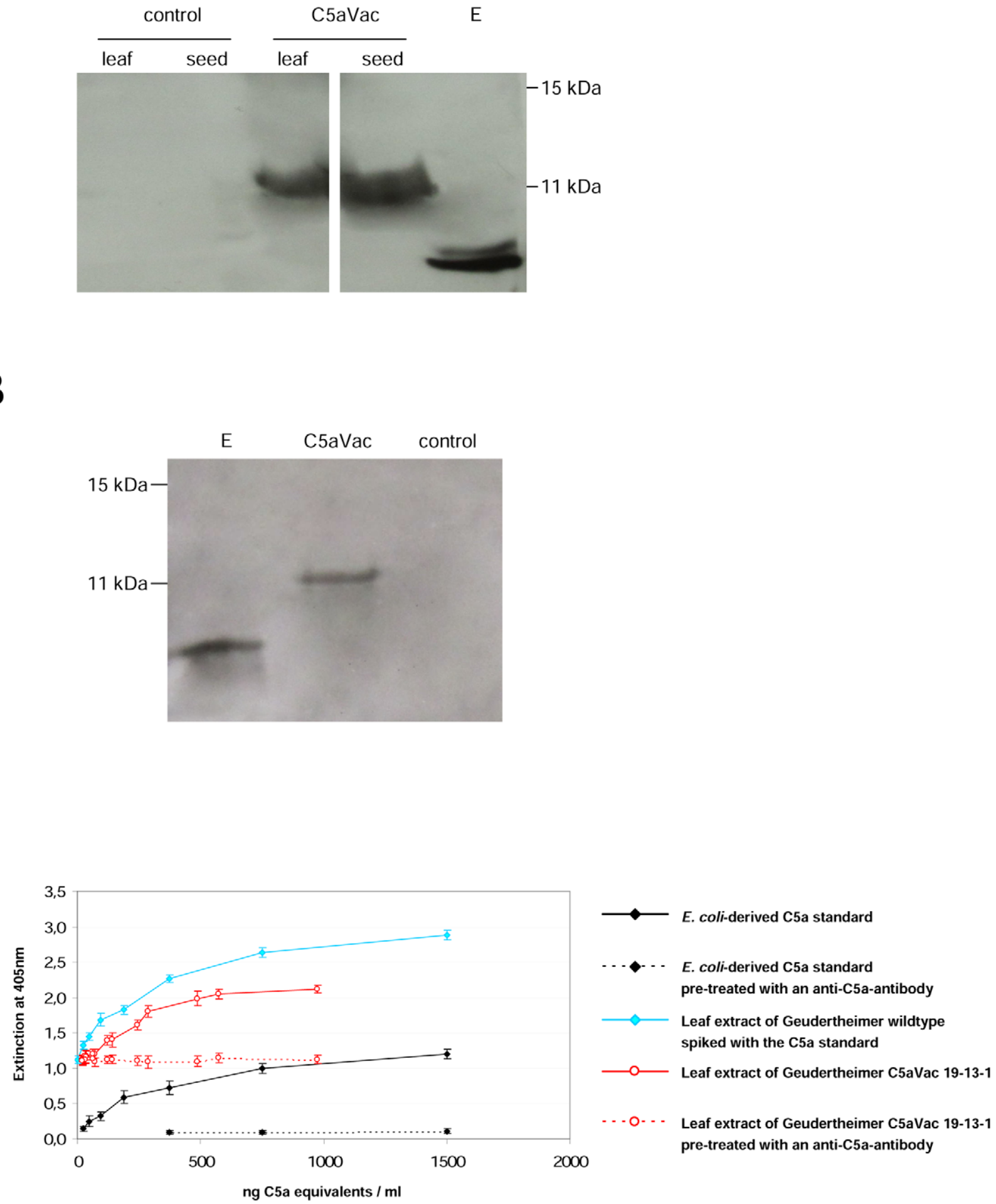

ng C5a equivalents / $\mathrm{ml}$

Figure 6. Western Blot analysis of leaf and seeds samples of transgenic Geudertheimer plants (100 $\mu$ g TSP); (A) Samples from stable transformed plants; E: 5 ng of recombinant C5a produced in E. coli; Control: leaf and seed samples from wild-type tobacco. C5aVac: leaf and seed samples of the $T_{2}$ individual C5aVac 19-13-15, expressing the vacuolar variant of C5a; (B) Samples from N. benthamiana at 6 dpi after Agroinfiltration; control: N. benthamiana transfected with the empty vector plCH29912; C5aVac: N. benthamiana transfected with plCH29912-C5aVac; $\mathrm{E}: 5 \mathrm{ng}$ of recombinant C5a produced in E. coli; (C) Verification of C5a biological activity using crude leaf extracts from transgenic tobacco and the near isogenic variant (wildtype) compared to a commercial standard C5a produced in E. coli. Enzyme release was measured by substrate conversion following exposure to different dilutions of the lead extracts, with the concentration of C5a determined by ELISA.

doi:10.1371/journal.pone.0053023.g006 
accumulation was an order of magnitude lower than in the vacuole. This suggests that C5a is specifically degraded in the ER because it is sensitive to the limited number of highly-specific proteases contained therein. Recently, this phenomenon has also been recorded for other proteins recombinant proteins [56-58]. The higher yields of vacuolar C5a indicate that the recombinant protein may be partially protected by virtue of its vacuolar destination, perhaps due to a shorter residence time in the ER. The vacuole therefore appears to be an appropriate target for recombinant proteins expressed in plants if they are susceptible to proteases in the secretory pathway.

Seeds accumulated 1.4-1.7 more C5a than leaves when the protein was targeted to the ER or the vacuole, probably reflecting the lower proteolytic activity [50] and the higher protein concentration in seeds $25 \%$ compared to $10 \%$ in tobacco leaves $[59,60]$. There was no difference between seeds and leaves when the protein was targeted to the apoplast, probably because this does not function as a storage compartment in either tissue. Interestingly, the only previous publication known to us that compares the accumulation of proteins in tobacco leaves and seeds using the CaMV $35 \mathrm{~S}$ promoter, reported yields of up to $5 \%$ of TSP in leaves and only $0.4 \%$ in seeds [61]. Since the transgene encoded protein is a relatively stable antibody, this difference might reflect the promoter activity, which is known to be less active in seeds compared to leaves [62]. Assuming, that C5a is more stable in seeds compared to leaves this might balance the lower activity of the promoter.

We noted a sharp increase in protein accumulation in both leaves and seeds between the $T_{0}$ and $T_{1}$ generations, which might reflect homozygosity of the transgene loci for the individuals 19-13 and 19-16 since the same integration loci are present. Phenomena like these have already been demonstrated [63]. However, the increase seems to be too pronounced to reflect only the doubling of the copy number. In addition, since all offspring of a selfed homozygous line should be homozygous, the $\mathrm{T}_{2}$ generation should show similar expression levels, which is not the case. Hence other factors might influence the increase in transgene expression, which has also been reported by others $[64,65]$.

The protein levels in the seeds were stable for more than three months providing a strong advantage over leaves, where proteins degrade soon after harvest and must be extracted promptly [50]. Tobacco seeds also lack many of the secondary metabolites that interfere with and increase the costs of downstream processing [66]. Morandini et al. [67] calculated that Arabidopsis is a realistic seed platform for the production of vaccines which are needed in moderate amounts, considering several growth cycles per year in the greenhouse, the high TSP content per fresh weight and the high expression levels of the recombinant protein above $1 \%$ TSP. Therefore tobacco, which provides comparable seeds yields, might also be suitable for the commercial production of recombinant C5a. The fact that the maximum yield we achieved in plants $(0.014 \%$ of TSP) falls some way short of the $0.65 \%$ of TSP achieved in E. coli [17] might possibly be improved by using strong seed-specific promoters and the use of other cultivars like maize, rice, barley and safflower which are currently the seed-based systems of choice for the expression of pharmaceuticals [68]. It remains to be seen if yields can be improved to the extent that the process becomes commercially competitive with microbial fermentation.

As alternative to stable transformed plants, transient expression systems are likely to be used for the commercial production of biopharmaceuticals because they can be established and scaled more rapidly than transgenic plants [23]. Using MagnICON vectors, $\mathrm{C} 5 \mathrm{aER}$ and $\mathrm{C} 5 \mathrm{aVac}$ reached up to $0.2 \%$ and $0.7 \%$ of
TSP, respectively, in $\mathcal{N}$. benthamiana. In case of $\mathrm{C} 5 \mathrm{aVac}$ this represents a 50fold increase compared to the best-performing transgenic $\mathrm{T}_{2}$ individual $\mathrm{C} 5 \mathrm{aVac}$ 19-13-15. The prodigious synthesis rate of the viral vector seems to be able to overcome the low accumulation levels that probably results from protein degradation. This phenomenon has already been recorded for other unstable proteins, including the hepatitis B virus surface antigen $(\mathrm{HbsAg})$, which accumulated at less than $0.01 \%$ TSP in transgenic tobacco leaves but up to $0.26 \%$ TSP using the MagnICON system [69], and the LTB-MUC1 protein which achieved yields of $3 \%$ TSP by transient expression [70]. Notably, the same difference between C5aER and C5aVac as observed in stable transformed Geudertheimer plants was recorded in the transient assay as well. However, transient overexpression in $\mathcal{N}$. benthamiana was accompanied by cytotoxic effects, which induced a premature leaf senescence for both constructs, starting at 5 dpi. Moreover, we recorded a rapid decrease of recombinant C5a in the dying leaves. Similarly, the transient expression of LTBMUC1 and the hepatitis B core antigen led to complete leaf necrosis [70,71]. Pinkhasov et al. [70] speculated that the recombinant protein might interfere with the plant metabolism and cause altered phenotype or cell death. This is more evident in the MagnICON viral vector system because of extremely high accumulation levels. Nevertheless, the reason for C5a-induced leaf necrosis remains unknown.

The C5a isolated from tobacco had a significantly higher molecular weight than the E. coli standard (Fig. 6). This might reflect the addition of $\mathcal{N}$-linked glycans at the $\mathrm{Asn}_{64}$ residue, which is also glycosylated in the native human protein [72]. In fact, the potential $\mathcal{N}$-glycosylation sites were found to be conserved between plants and animals [73-75]. The assumption that plant derived C5a is glycosylated is also supported by the fact that, the $\mathrm{EC}_{50}$ value of plant-derived C5aVac of $279.46 \mathrm{ng}$ C5a equivalents/ml was different compared to that of $E$. coli-derived counterpart with 192.03 ng C5a equivalents/ml [17]. Using the plant extract spiked with $E$. coli derived C5a we could prove that this difference is not due to endogenous metabolites or enzymes present in the crude extract. Nevertheless, additional experiments need to be done in order to prove that plant-derived C5a is glycosylated.

\section{Supporting Information}

Figure S1 Sequence of the IL6 signal peptide including three triplets downstream the initiator codon ATG (underlined) that increase the efficiency of recognition. (DOG)

Figure S2 Sequence of the mature C5a gene product, derived from the precursor $\mathrm{C} 5$. (DOG)

Figure S3 Compartment specific C-terminal variants of G5 a codon-optimized for tobacco. (DOC)

\section{Acknowledgments}

This work was supported by the doctorate program of the University of Rostock. The authors thank Dr. Anatoli Giritch and Prof. Dr. Juri Gleba for providing the MagnICON vectors for research purposes.

\section{Author Contributions}

Conceived and designed the experiments: HN HM IB. Performed the experiments: HN. Analyzed the data: HN HM IB JH. Contributed reagents/materials/analysis tools: IB UM. Wrote the paper: HN HM IB. Performed the C5a-bioassay: RK. 


\section{References}

1. Riedemann NC, Guo RF, Ward PA (2003) Novel strategies for the treatment of sepsis. Nature Medicine 9: 517-524.

2. Cohen J (2009) Non-antibiotic strategies for sepsis. Clinical Microbiology and Infection 15: 302-307.

3. Dombrovskiy VY, Martin AA, Sunderram J, Paz HL (2007) Rapid increase in hospitalization and mortality rates for severe sepsis in the United States: a trend analysis from 1993 to 2003. Crit Care Med 35: 1244-1250.

4. Parrish WR, Gallowitsch-Puerta M, Czura CJ, Tracey KJ (2008) Experimental Therapeutic Strategies for Severe Sepsis Mediators and Mechanisms. Neural Signaling: Opportunities for Novel Diagnostic Approaches and Therapies 1144: 210-236.

5. Flierl MA, Stahel PF, Rittirsch D, Huber-Lang M, Niederbichler AD, et al. (2009) Inhibition of complement C5a prevents breakdown of the blood-brain barrier and pituitary dysfunction in experimental sepsis. Critical Care 13.

6. Guo RF, Ward PA (2005) Role of C5A in inflammatory responses. Annual Review of Immunology 23: 821-852.

7. Ward PA (2008) Role of the complement in experimental sepsis. Journal of Leukocyte Biology 83: 467-470.

8. Christie M, Croft LJ, Carroll BJ (2011) Intron splicing suppresses RNA silencing in Arabidopsis. Plant Journal 68: 159-167.

9. Czermak BJ, Sarma V, Pierson CL, Warner RL, Huber-Lang M, et al. (1999) Protective effects of C5a blockade in sepsis. Nature Medicine 5: 788-792.

10. Huber-Lang MS, Younkin EM, Sarma JV, McGuire SR, Lu KT, et al. (2002) Complement-induced impairment of innate immunity during sepsis. Journal of Immunology 169: 3223-3231.

11. Niederbichler AD, Hoesel LM, Westfall MV, Gao H, Ipaktchi KR, et al. (2006) An essential role for complement C5a in the pathogenesis of septic cardiac dysfunction. J Exp Med 203: 53-61.

12. Rittirsch D, Flierl MA, Ward PA (2008) Harmful molecular mechanisms in sepsis. Nat Rev Immunol 8: 776-787.

13. Tripathi NK, Sathyaseelan K, Jana AM, Rao PVL (2009) High Yield Production of Heterologous Proteins with Escherichia coli. Defence Science Journal 59: 137-146.

14. Franke AE, Andrews GC, Stimlergerard NP, Gerard CJ, Showell HJ (1988) Human C5A Anaphylatoxin - Gene Synthesis, Expression, and Recovery of Biologically-Active Material from Escherichia-Coli. Methods in Enzymology 162: 653-668.

15. Mandecki W, Powell BS, Mollison KW, Carter GW, Fox JL (1986) High-Level Expression of A Gene Encoding the Human-Complement Factor C5A in Escherichia-Coli. Gene 43: 131-138.

16. Mollison KW, Fey TA, Krause RA, Mandecki W, Fox JL, et al. (1987) HighLevel C5A Gene-Expression and Recovery of Recombinant Human C5A from Escherichia-Coli. Agents and Actions 21: 366-370.

17. Nausch H, Huckauf J, Koslowski R, Meyer U, Broer I, et al. (2012) Recombinant production of human complement factor 5a in Escherichia coli. African Journal of Biotechnology (submitted).

18. Huang CJ, Lin H, Yang XM (2012) Industrial production of recombinant therapeutics in Escherichia coli and its recent advancements. Journal of Industrial Microbiology \& Biotechnology 39: 383-399.

19. Tremblay R, Wang D, Jevnikar AM, Ma SW (2010) Tobacco, a highly efficient green bioreactor for production of therapeutic proteins. Biotechnology Advances 28: $214-221$.

20. Boehm R (2007) Bioproduction of therapeutic proteins in the 21st century and the role of plants and plant cells as production platforms. Biology of Emerging Viruses: Sars, Avian and Human Influenza, Metapneumovirus, Nipah, West Nile, and Ross River Virus 1102: 121-134.

21. Thomas DR, Penney CA, Majumder A, Walmsley AM (2011) Evolution of Plant-Made Pharmaceuticals. International Journal of Molecular Sciences 12: 3220-3236.

22. Avesani L, Bortesi L, Santi L, Falorni A, Pezzotti M (2010) Plant-made pharmaceuticals for the prevention and treatment of autoimmune diseases: where are we? Expert Review of Vaccines 9: 957-969.

23. Fischer R, Schillberg S, Hellwig S, Twyman RM, Drossard J (2012) GMP issues for recombinant plant-derived pharmaceutical proteins. Biotechnology Advances 30: 434-439.

24. Obembe OO, Popoola JO, Leelavathi S, Reddy SV (2011) Advances in plant molecular farming. Biotechnology Advances 29: 210-222.

25. Paul M, Ma JKC (2011) Plant-made pharmaceuticals: Leading products and production platforms. Biotechnology and Applied Biochemistry 58: 58-67.

26. Tiwari S, Mishra DK, Roy S, Singh A, Singh PK, et al. (2009) High level expression of a functionally active cholera toxin $\mathrm{B}$ : rabies glycoprotein fusion protein in tobacco seeds. Plant Cell Reports 28: 1827-1836.

27. Schillberg S, Zimmermann S, Voss A, Fischer R (1999) Apoplastic and cytosolic expression of full-size antibodies and antibody fragments in Nicotiana tabacum. Transgenic Research 8: 255-263.

28. Sawant SV, Kiran K, Singh PK, Tuli R (2001) Sequence architecture downstream of the initiator codon enhances gene expression and protein stability in plants. Plant Physiology 126: 1630-1636.

29. Hausmann L, Töpfer R (1999) Entwicklung von Plasmid-Vektoren. Vortr. Pflanzenzüchtung 45: 155-172.
30. Herreraestrella L, Deblock M, Messens E, Hernalsteens JP, Vanmontagu M, et al. (1983) Chimeric Genes As Dominant Selectable Markers in Plant-Cells. Embo Journal 2: 987-995.

31. Odell JT, Nagy F, Chua NH (1985) Identification of Dna-Sequences Required for Activity of the Cauliflower Mosaic Virus-35S Promoter. Nature 313: 810812.

32. Gallie DR, Sleat DE, Watts JW, Turner PC, Wilson TMA (1987) The 5'-Leader Sequence of Tobacco Mosaic-Virus Rna Enhances the Expression of Foreign Gene Transcripts Invitro and Invivo. Nucleic Acids Research 15: 3257-3273.

33. Denecke J, Derycke R, Botterman J (1992) Plant and Mammalian Sorting Signals for Protein Retention in the Endoplasmic-Reticulum Contain A Conserved Epitope. Embo Journal 11: 2345-2355.

34. Frigerio L, Foresti O, Felipe DH, Neuhaus JM, Vitale A (2001) The C-terminal tetrapeptide of phaseolin is sufficient to target green fluorescent protein to the vacuole. Journal of Plant Physiology 158: 499-503.

35. Marillonnet S, Giritch A, Gils M, Kandzia R, Klimyuk V, et al. (2004) In planta engineering of viral RNA replicons: Efficient assembly by recombination of DNA modules delivered by Agrobacterium. Proceedings of the National Academy of Sciences of the United States of America 101: 6852-6857.

36. Engler C, Kandzia R, Marillonnet S (2008) A One Pot, One Step, Precision Cloning Method with High Throughput Capability. Plos One 3.

37. Bendandi M, Marillonnet S, Kandzia R, Thieme F, Nickstadt A, et al. (2010) Rapid, high-yield production in plants of individualized idiotype vaccines for non-Hodgkin's lymphoma. Annals of Oncology 21: 2420-2427.

38. Horsch RB, Fry JE, Hoffmann NL, Eichholtz D, Rogers SG, et al. (1985) A Simple and General-Method for Transferring Genes Into Plants. Science 227: 1229-1231.

39. Giritch A, Marillonnet S, Engler C, van Eldik G, Botterman J, et al. (2006) Rapid high-yield expression of full-size IgG antibodies in plants coinfected with noncompeting viral vectors. Proceedings of the National Academy of Sciences of the United States of America 103: 14701-14706.

40. Liu JZ, Blancaflor EB, Nelson RS (2005) The tobacco mosaic virus 126kilodalton protein, a constituent of the virus replication complex, alone or within the complex aligns with and traffics along microfilaments. Plant Physiology 138: 1853-1865

41. Khanuja SPS, Shasany AK, Darokar MP, Kumar S (1999) Rapid isolation of DNA from dry and fresh samples of plants producing large amounts of secondary metabolites and essential oils. Plant Molecular Biology Reporter 17: 74-74.

42. Ali H, Richardson RM, Tomhave ED, Didsbury JR, Snyderman R (1993) Differences in Phosphorylation of Formylpeptide and C5A Chemoattractant Receptors Correlate with Differences in Desensitization. Journal of Biological Chemistry 268: 24247-24254.

43. Goldstei.Im, Weissman.G (1974) Generation of C5-Derived Lysosomal EnzymeReleasing Activity (C5A) by Lysates of Leukocyte Lysosomes. Journal of Immunology 113: 1583-1588.

44. Nausch H, Mikschofsky H, Koslowski R, Meyer U, Broer I, et al. (2012) Highlevel transient expression of ER-targeted human interleukin 6 in Nicotiana benthamiana. PLoS One (submitted).

45. Komarova TV, Baschieri S, Donini M, Marusic C, Benvenuto E, et al. (2010) Transient expression systems for plant-derived biopharmaceuticals. Expert Review of Vaccines 9: 859-876.

46. Yang SJ, Carter SA, Cole AB, Cheng NH, Nelson RS (2004) A natural variant of a host RNA-dependent RNA polymerase is associated with increased susceptibility to viruses by Nicotiana benthamiana. Proceedings of the National Academy of Sciences of the United States of America 101: 6297-6302.

47. Davies HM (2010) Commercialization of whole-plant systems for biomanufacturing of protein products: evolution and prospects. Plant Biotechnology Journal 8: 845-861.

48. Hugli TE (1984) Structure and Function of the Anaphylatoxins. Springer Seminars in Immunopathology 7: 193-219.

49. Mollison KW, Fey TA, Krause RA, Miller L, Edalji RP, et al. (1991) C5a structural requirements for neutrophil receptor interaction. Agents Actions Suppl 35: 17-21.

50. Benchabane M, Goulet C, Rivard D, Faye L, Gomord V, et al. (2008) Preventing unintended proteolysis in plant protein biofactories. Plant Biotechnology Journal 6: 633-648.

51. Doran PM (2006) Foreign protein degradation and instability in plants and plant tissue cultures. Trends in Biotechnology 24: 426-432.

52. Conrad U, Fiedler U (1998) Compartment-specific accumulation of recombinant immunoglobulins in plant cells: an essential tool for antibody production and immunomodulation of physiological functions and pathogen activity. Plant Molecular Biology 38: 101-109.

53. Vitale A, Pedrazzini E (2005) Recombinant pharmaceuticals from plants: The plant endomembrane system as bioreactor. Molecular Interventions 5: 216-225.

54. Khan I, Twyman R, Arcalis E, Stoger E (2012) Using storage organelles for the accumulation and encapsulation of recombinant proteins. J Biotechnol (online ahead of print).

55. Goulet C, Khalf M, Sainsbury F, D'Aoust MA, Michaud D (2012) A protease activity-depleted environment for heterologous proteins migrating towards the leaf cell apoplast. Plant Biotechnology Journal 10: 83-94. 
56. Hehle VK, Paul MJ, Drake PM, Ma JKG, van Dolleweerd CJ (2011) Antibody degradation in tobacco plants: a predominantly apoplastic process. Bmc Biotechnology 11.

57. Pagny S, mat-Ouisse LA, Gomord V, Faye L (2003) Fusion with HDEL protects cell wall invertase from early degradation when $\mathrm{N}$-glycosylation is inhibited. Plant and Cell Physiology 44: 173-182.

58. Sharp JM, Doran PM (2001) Characterization of monoclonal antibody fragments produced by plant cells. Biotechnology and Bioengineering 73: 338-346.

59. Frega N, Bocci F, Conte LS, Testa F (1991) Chemical-Composition of Tobacco Seeds (Nicotiana-Tabacum-L). Journal of the American Oil Chemists Society 68: 29-33.

60. Torikaiu K, Uwano Y, Nakamori T, Tarora W, Takahashi H (2005) Study on tobacco components involved in the pyrolytic generation of selected smoke constituents. Food and Chemical Toxicology 43: 559-568.

61. Petruccelli S, Otegui MS, Lareu F, Dinh OT, Fitchette AC, et al. (2006) A KDEL-tagged monoclonal antibody is efficiently retained in the endoplasmic reticulum in leaves, but is both partially secreted and sorted to protein storage vacuoles in seeds. Plant Biotechnology Journal 4: 511-527.

62. Boothe J, Nykiforuk C, Shen Y, Zaplachinski S, Szarka S, et al. (2010) Seedbased expression systems for plant molecular farming. Plant Biotechnology Journal 8: 588-606.

63. Twyman RM, Schillberg S, Fischer R (2012) Optimizing the yield of recombinant pharmaceutical proteins in plants. Current Pharmaceutical Design (in press).

64. Huhns M, Neumann K, Hausmann T, Klemke F, Lockau W, et al. (2009) Tuber-specific cphA expression to enhance cyanophycin production in potatoes. Plant Biotechnology Journal 7: 883-898.

65. Mikschofsky H, Schirrmeier H, Keil GM, Lange B, Polowick PL, et al. (2009) Pea-derived vaccines demonstrate high immunogenicity and protection in rabbits against rabbit haemorrhagic disease virus. Plant Biotechnology Journal 7: 537-549.

66. Lau OS, Sun SSM (2009) Plant seeds as bioreactors for recombinant protein production. Biotechnology Advances 27: 1015-1022.

67. Morandini F, Avesani L, Bortesi L, Van Droogenbroeck B, De Wilde K, et al. (2011) Non-food/feed seeds as biofactories for the high-yield production of recombinant pharmaceuticals. Plant Biotechnology Journal 9: 911-921.

68. Mikschofsky H, Broer I (2012) Feasibility of Pisum sativum as an expression system for pharmaceuticals. Transgenic Research 21: 715-724.

69. Huang Z, LePore K, Elkin G, Thanavala Y, Mason HS (2008) High-yield rapid production of hepatitis $\mathrm{B}$ surface antigen in plant leaf by a viral expression system. Plant Biotechnology Journal 6: 202-209.

70. Pinkhasov J, Alvarez ML, Rigano MM, Piensook K, Larios D, et al. (2011) Recombinant plant-expressed tumour-associated MUC1 peptide is immunogenic and capable of breaking tolerance in MUC1.Tg mice. Plant Biotechnology Journal 9: 991-1001.

71. Huang Z, Santi L, LePore K, Kilbourne J, Arntzen CJ, et al. (2006) Rapid, highlevel production of hepatitis $B$ core antigen in plant leaf and its immunogenicity in mice. Vaccine 24: 2506-2513.

72. Fernandez HN, Hugli TE (1978) Primary Structural-Analysis of Polypeptide Portion of Human C5A Anaphylatoxin - Polypeptide Sequence Determination and Assignment of Oligosaccharide Attachment Site in C5A. Journal of Biological Chemistry 253: 6955-6964.

73. Jacobs PP, Callewaert N (2009) N-glycosylation Engineering of Biopharmaceutical Expression Systems. Current Molecular Medicine 9: 774-800.

74. Nagels B, Weterings K, Callewaert N, Van Damme EJM (2012) Production of Plant Made Pharmaceuticals: From Plant Host to Functional Protein. Critical Reviews in Plant Sciences 31: 148-180.

75. Webster DE, Thomas MC (2012) Post-translational modification of plant-made foreign proteins; glycosylation and beyond. Biotechnology Advances 30: 410418. 